bridge of cartilage and close to it a large serous gland composed of four lobes with numerous excretory ducts.

Five years later the patient was brought to me again on account of tumours in both eyes. In the right eye the site of the congenital tumour described above was thickened and slightly pigmented, thinning towards the cornea. On the upper part of this eye, $5 \mathrm{~mm}$. from the cornea, there were two small yellowish tumours covered by the conjunctiva which was not adherent to them (Figs. 3 and 4). On the left eye there was a tumour a little bigger than an almond, widest near the cornea, and extending to the base of the inferior conjunctival cul-de-sac, at which part it was more prominent.

There was no change in the skin of the face and head. The blood Wassermann reaction was negative.

The tumours were removed under general anaesthesia, and were easily separable from the conjunctiva. The tumour of the left eye was connected with the orbital contents and had to be cut away from them.

Microscopical examination showed that the tumours consisted of adipose and glandular tissue. They resembled the cases described by Parinaud, Lanelongue, and van Duyse under the name of dermo-epithelioma.

The classical dermoid contains all the elements of the skin, epidermis, derma, papillae, and glands. Cartilage and adipose tissue also may occur. van Duyse suggests that some amniotic adhesion may play a part in their production.

In addition to the complexity of the structure shown in my case. the lumours were not situated in the usual position, i.e., the superoexternal part of the eye.

\title{
A CASE OF DOUBLE DIABETIC CATARACT. EXTRACTION AFTER USE OF INSULIN TREATMENT
}

BY

Professor Ellena Puscariu, Dr. J. Nitzulescu, AND DR. EC. TRIANDAF

ROUMANIA

THE case here related came under our observation last summer and was shown at the Roumanian Ophthalmological Society. In view of the excellent results obtained by operation in a case of bilateral diabetic cataract after insulin treatment we consider the case worthy of record. 
Insulin has been employed in ophthalmology soon after its discovery for a variety of diabetic affections. Thus Poyales ${ }^{(10)}$ found that it increased the power of accommodation while reducing the glycosuria and glycaemia; Duke-Elder ${ }^{(5)}$ also obtained a modification of the refraction of the eye; W. Hardy ${ }^{(8)}$, in a case of juvenile diabetes with characteristic retinal oedema and lipaemia, restored the appearance of the fundus to normal after three days treatment; and Chauffard, Grigaut, and $\mathrm{Nida}^{(3)}$ saw the disappearance of the characteristic white patches. Graefe ${ }^{(7)}$ noted that insulin was more efficacious than any dietetic measures in the treatment of incipient retrobulbar neuritis with scotomata.

In cases of diabetic cataract insulin exercises a favourable action by modifying the abnormal local conditions, re-establishing the saline equilibrium, and opposing the acidosis of the aqueous, while simultaneously modifying the condition of the blood. Thus, Fisher ${ }^{(6)}$, Wirth ${ }^{(11)}$, succeeded in obtaining the absorption of incipient diabetic cataract. In cases of mature cataract insulin remains as an indispensable aid to successful operation. It acts both by improving the general condition of the patient, and also by preventing the complications of iritis, sepsis, and delayed healing that so frequently occur in cases of extraction of diabetic cataracts. While dietetic measures may suffice in the very mild cases, insulin is indispensable in those of greater severity. As a rule in cases of moderate severity there is no need of large doses of insulin. Nichelatti ${ }^{(9)}$ published a case in which 20 units daily sufficed, and Poyales also recorded a similar case. Nichelatti was satisfied by the reduction of the sugar in the urine to 0.8 per cent. It is worthy of note that in his case the early cessation of treatment resulted in an iritis which did not yield to treatment until the insulin was again used.

The following is an account of our case :

The patient, Nicolas $-D$., a peasant, aged 34 years, has always been weakly, and was rejected for military service. No very definite history was obtainable, but he seemed to have suffered from malaria and parotitis. He has been confined to bed for the last year on account of general weakness accompanied by muscular pains. For the last four months he has had defective vision, the sight of the right eye being completely lost in a few weeks while that of the left was considerably diminished. During his illness he complained of excessive hunger and thirst with progressive weakness.

When first seen he was much emaciated with a dry and icthyotic skin. The breath sounds were modified at both pulmonary apices and radioscopy showed a shadow at the left apex and some calcification in the right upper lobe. Liver and spleen normal. Deep 
reflexes were absent but cutaneous reflexes were normal; sensation was unaffected. The Wassermann reaction was negative. Glycaemia was 0.5 per cent., cholesterinaemia 0.19 per cent., and glycosuria approximately $150-250 \mathrm{gms}$. in twenty-four hours. There were no ketones in the urine and the kidney functions were normal. Ambard's constant was 0.08 , and Volhard's test for the power of dilution and concentration was within normal limits. The quantity of urine passed in twenty four hours was from 2,000 to 3,000 c.c. Urea was 0.4 per cent. No tubercle bacilli were found in the sputum.

Ophthalmological examination: Vision was reduced to perception of light in both eyes. Projection good. Tension $21 \mathrm{~mm}$. Schiötz.

The patient's general condition and the large quantity of sugar in the urine indicated the gravity of the case. We, therefore, kept him under observation for eighteen days on a diet relatively poor in carbohydrates, and then for three days on a standard diet (Chabanier) containing $150 \mathrm{gms}$. of carbohydrates. As there was but little change in the sugar condition we started insulin treatment (see Table).

Seven days later the right lens was extracted with iridectomy and capsulectomy, a similar operation being performed on the left eye four days later. When he left the hospital the visual acuity in the right eve was 0.7 with correction; that of the left was only 0.1. The defective vision of the latter was due to lens remnants and an inferior synechia.

We did not adopt Nichelatti's method of first completely reducing the carbohydrates and then using a minimal dose of insulin, since the patient's general nutrition was too low. We considered it safer to continue the standard diet with $150 \mathrm{gm}$. carbohydrate and 1,600-1,800 calories, and use larger doses of insulin. On the days of operation the diet was diminished, and he was allowed only a little milk, tea, and oatmeal porridge. We succeeded in obtaining the complete disappearance of sugar from the urine and not merely its diminution. In this case the result was easily obtained, and, in spite of the large doses of insulin, there were only slight signs of hypoglycaemia (sweating, anxiety) which were readily removed by oatmeal porridge or a cup of tea with a grain of sugar.

We regret that as we were unable to make serial estimations of the glvcaemia, we are unable to offer a satisfactory explanation for the fact that we had to use incomparably smaller doses of insulin with the same diet at the end of the treatment than at the beginning in order to keep the urine free from sugar. Possibly during the first few davs part of the effect of the insulin is used in opposing the hyperglycaemia. Chabanier ${ }^{(2)}$ suggests that 
insulin produces a raising of the renal threshold for sugar, so that a higher degree of glycaemia is necessary for the production of glycosuria.

Our patient would not consent to any stricter diet and any surgical intervention would have been impossible without the aid of insulin. He refused to stay in the clinic longer than eighteen days after the second operation. For the last few days we were compelled to yield to his persistent demands for bread so that when he left the glycosuria was no better than on admission. We believe that his general condition might have been much improved by a longer course of treatment.

\section{BIBLIOGRAPHY}

1. Chabanier, L.-On the treatment of diabetes by insulin. Presse Med., Vol. XXXIII, p. 353, 1922.

2. Idem. - The rôle of the kidney in diabetes. Thèse de Paris, 1923.

3. Chaufard, G.-A case of diabetic retinitis much improved by insulin. Compt. Rend. Soc. Biol., 1923.

4. Dentrelle.-Diabetic cataract and insulin. Ann. d'Ocul., 1926.

5. Duke-Elder, W. S. - Changes in refraction in diabetes mellitus. Brit. Jl. of Ophthal., Vol. IX, 1925.

6. Fisher.-Ophthal. Gesellsch., Wien.

7. Graefe.-Ophthal. Gesellsch., Heidelberg, 1924.

8. Hardy, W.-Amer. Jl. of Ophthal., 1924.

9. Nichelatti.-Insulin and ocular surgery in the diabetic. Let. Oftal., 1924.

10. Poyales.-Insulin in ophthalmology. Arch. d'Ophtal., 1924.

11. Wirth.-Ophthal, Gesellsch., Heidelberg.

\begin{tabular}{|c|c|c|c|c|c|}
\hline Date. & Diet. & $\begin{array}{l}\text { Insulin } \\
\text { units. }\end{array}$ & $\begin{array}{l}\text { Sugar in } \\
\text { urine, daily } \\
\text { amount in } \\
\text { gms. }\end{array}$ & $\begin{array}{l}\text { Carbo- } \\
\text { hydrate } \\
\text { balance } \\
\text { in gms. }\end{array}$ & Observations. \\
\hline \multicolumn{6}{|l|}{$26 / \mathrm{VII}$ to } \\
\hline $30 / \mathrm{VII} \quad \ldots$ & $\begin{array}{l}150 \text { gms. carbo- } \\
\text { hydrate; } 90 \text { gms. } \\
\text { fat ; } 71 \text { gms. pro- } \\
\text { tein ( } 1,700 \text { calories })\end{array}$ & 0 & $200-300$ & $\begin{array}{l}-50 \\
-150\end{array}$ & Wt. $34,500 \mathrm{Kg}$. \\
\hline 30/VII $\ldots$ & The same. & 15 & 150 & 0 & - \\
\hline $31 /$ VII $\ldots$ & The same. & 30 & 115 & +35 & - \\
\hline 1/VIII... & The same. & 40 & 180 & -30 & - - \\
\hline $2 /$ VIII... & The same. & 90 & 19 & +130 & $\begin{array}{l}\text { Slight hypogly- } \\
\text { caemia relieved } \\
\text { by tea and sugar. }\end{array}$ \\
\hline 3/VIII... & The same. & 45 & 12 & +138 & $\begin{array}{l}30 \text { gms. carbohy- } \\
\text { drate, oatmeal. }\end{array}$ \\
\hline
\end{tabular}




\begin{tabular}{|c|c|c|c|c|c|}
\hline Date. & Diet. & $\begin{array}{l}\text { Insulin } \\
\text { units }\end{array}$ & $\begin{array}{l}\text { Sugar in } \\
\text { urine, daily } \\
\text { amount in } \\
\text { gms. }\end{array}$ & $\begin{array}{l}\text { Carbo- } \\
\text { hydrate } \\
\text { balance } \\
\text { in gms. }\end{array}$ & Observations. \\
\hline 4/VIII... & $\begin{array}{l}150 \text { gms. carbo- } \\
\text { hydrate; } 90 \text { gms. } \\
\text { fat; } 71 \text { gms. pro- } \\
\text { tein }(1,700 \text { calories })\end{array}$ & 70 & Traces. & +150 & $\begin{array}{l}\text { Slight hypogly- } \\
\text { caemia, oatmeal } \\
\text { and sugar. }\end{array}$ \\
\hline 5/VIII... & $\begin{array}{l}91 \text { gms. carbo- } \\
\text { hydrate; } 36 \text { gms. } \\
\text { fat ; } 40 \text { gms. pro- } \\
\text { tein ( } 810 \text { calories). }\end{array}$ & 35 & Traces. & +150 & $\begin{array}{l}\text { Operation right } \\
\text { eye. }\end{array}$ \\
\hline 6/VIII... & $\begin{array}{l}153 \text { gms. carbo- } \\
\text { hydrate; } 46 \text { gms. } \\
\text { fat; } 68 \text { gms. pro- } \\
\text { tein }(1,240 \text { calories })\end{array}$ & 50 & None. & +150 & $\begin{array}{l}\text { Afternoon tea with } \\
\text { sugar. }\end{array}$ \\
\hline 7/VIII... & $\begin{array}{l}125 \text { gms. carbo- } \\
\text { hydrate; } 104 \text { gms. } \\
\text { fat; } 116 \text { gms. pro- } \\
\text { tein }(1,810 \text { calories })\end{array}$ & 50 & None. & +125 & - \\
\hline 8/VIII... & The same. & 40 & None. & +125 & - \\
\hline 9/VIII... & $\begin{array}{l}130 \text { gms. carbo- } \\
\text { hydrate ; } 60 \text { gms. } \\
\text { fat ; } 63 \text { gms. pro- } \\
\text { tein }(1,260 \text { calories })\end{array}$ & 40 & None. & +130 & $\begin{array}{l}\text { Operation left eye, } \\
\text { slight hypogly- } \\
\text { caemia in after- } \\
\text { noon. }\end{array}$ \\
\hline $10 /$ VIII ... & The same. & 40 & None. & +130 & - \\
\hline $11 /$ VIII ... & $\begin{array}{l}140 \text { gms. carbo- } \\
\text { hydrate; } 90 \text { gms. } \\
\text { fat ; } 100 \text { gms. pro- } \\
\text { tein }(1,700 \text { calories })\end{array}$ & 30 & None. & +140 & - \\
\hline $12 /$ VIII ... & The same. & 25 & Traces. & +140 & - \\
\hline $13 /$ VIII ... & The same. & 20 & 30 & +110 & - \\
\hline $14 /$ VIII ... & The same. & 40 & Traces. & +140 & - \\
\hline 15/VIII ... & The same. & 35 & None. & +140 & - \\
\hline $16 /$ VIII ... & $\begin{array}{l}120 \text { gms. carbo- } \\
\text { hydrate; } 90 \text { gms. } \\
\text { fat ; } 106 \text { gms. pro- } \\
\text { tein }(1,650 \text { calories })\end{array}$ & 20 & None. & +120 & - \\
\hline $17 /$ VIII ... & The same. & 15 & Traces. & +120 & - \\
\hline $18 /$ VIII ... & The same. & 15 & None. & +120 & - \\
\hline 19/VIII. & The same. & 15 & None. & +120 & - \\
\hline 20/VIII ... & The same. & 10 & None. & +120 & - \\
\hline 21/VIII.. & The same. & 10 & None. & +120 & - \\
\hline 22/VIII... & The same. & 5 & None. & +120 & - \\
\hline 23/VIII . & $\begin{array}{l}80 \text { gms. carbo- } \\
\text { hydrate ; } 60 \text { gms. } \\
\text { fat; } 80 \text { gms. pro- } \\
\text { tein }(1,130 \text { calories })\end{array}$ & 0 & 15 & +65 & Insulin stopped. \\
\hline $24 /$ VIII $\ldots$ & The same. & 0 & 12 & +68 & - \\
\hline $25 /$ VIII ... & The same. & 0 & 11 & +69 & - \\
\hline 26/VIII.. & $\begin{array}{l}150 \text { gms. bread } \\
\text { added to diet. }\end{array}$ & 0 & 58 & +100 & 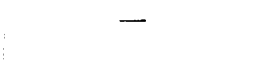 \\
\hline $27 /$ VIII ... & $\begin{array}{l}250 \text { gms. bread } \\
\text { added to diet (about } \\
135 \text { gms. carbo- } \\
\text { hydrate). }\end{array}$ & 0 & 145 & +70 & Left the hospital. \\
\hline
\end{tabular}

